\title{
The Uses of the European Past in American Historiography
}

\author{
by HANS R. GUGGISBERG \\ University of Basel
}

American historiography has always been preoccupied with American history. This is still the case in our present time. It is a natural phenomenon which applies in the same sense to other nations. Like other nations, too, America has always had historians who devoted themselves partly or exclusively to the study of the history of foreign lands. Within their guild they always were and still are a minority. Their position vis-à-vis the reading public and also vis-áa-vis the subjects of their interest is more problematic than that of the historians who concentrate on the national past. For the American historian of foreign lands the question of a specific historical sense is not only inescapable but also more difficult to answer than for his colleague who writes on American history. As Leonard Krieger has pointed out a few years ago, this historical sense may be defined as the capacity to understand the temporally distant in its own terms together with the consciousness of its relations with the familiar. When the American historian of extra-American (i.e. in our case European) history finds the temporal distance extended by the geographical and cultural distance, he is quite naturally tempted to start out by asking of his subject: 'What is it to me or I to it that I should aspire to study and understand it?' This basic question can lead to interesting historiographical results, but it can also lead into the sterility of mere antiquarianism. ${ }^{1}$

It is quite evident that these same perils also threaten the European historian who studies a problem in a European field outside the history of his own country. There is, however, an important difference: although the temporal distance is the same, the geographical and cultural distance is always shorter. Even in our time of microfilms, photostats, travel grants and visiting professorships, it still remains something else for an American to become a specialist of, say, the Italian Renaissance than for a German

${ }^{1}$ Leonard Krieger, 'European History in America', in John Higham, Leonard Krieger, Felix Gilbert, History (Humanistic Scholarship in America, The Princeton Studies, Englewood Cliffs, N.J.: Prentice-Hall, 1965), p. 235. 


\section{Hans R. Guggisberg}

or an Englishman. The American still has to overcome more technical obstacles on the way toward the subject of his interest. But first of all he needs a strong and unwavering conviction of the basic unity of Western history. If, in the course of his studies, he has gained this conviction and then sets out to write European history, he has gone through a longer and less self-evident development than the European whose ancestors never turned their backs to the Old World. The greater distance of the American's point of observation does not have to be a disadvantage, however. A wider horizon can be surveyed at one glance, and details which seem to justify controversy when examined at close range may lose their significance in favour of the general contours of the wide plains and hills which link the great peaks to each other. If the distant observer strives to explore a certain summit or a particular valley and takes upon himself the toils of a long and difficult journey, he always carries in his mind this picture of the whole horizon, and while on his way he has a great deal of time to meditate upon it.

Old and new American works on European history are not interesting merely because in some instances they contain original interpretations of certain facts or developments. They also show us what kind of European topics were of particular importance to educated Americans in particular periods of time. In addition to reflecting various historiographical influences from Europe they help us recognize the changing pattern of the Old World's image in the New. And this is the reason why a considerable number of them are of general significance to the student of American intellectual history. It goes without saying that in this context their scholarly qualities are often less important than their weaknesses.

It cannot be doubted that a discussion of the uses of the European past in American historiography is incomplete as long as it is concerned exclusively with works on European topics. It ought also to take into account the great achievements in the field of American history and examine their treatments of the European background. We will indeed have to point to some of these works, but for the sake of clarity I should like to base the following remarks mainly on the American contribution to European history proper.

If we look over the whole development of interest in European history within the general development of American historiography, we can distinguish two basically different ways of linking the history of the Old World to the historical experience of America. The first is characterized by a chronological conception: European history is considered mainly as a pre-history of America, as a kind of introductory phase in which the ideas and traditions that were to make the American nation what it is, began to emerge but did not find their true and lasting fulfilment. The second 
approach is based on the consciousness of a historical community in which America and Europe play equal roles as parts of the same Western World. The first approach naturally led American scholars to the study of the earlier periods of European history, while the second furthered their interest in the more recent developments. In addition to this it can be generally observed that American historians who adopted the first way of looking at the European past tended to be primarily interested in the history of political institutions, religion and culture, while the adherents of the second method showed a distinctive preference for problems of international relations, diplomatic and economic history. But we must be careful not to oversimplify our case. It is not possible to define every American book as belonging to one or the other of these categories. In the minds of many authors both ways of looking at the European past seem to have melted into each other. There are, on the other hand, historians of great fame whose stand can be rather easily recognized. The conviction of the basic unity of European and American history is always there; the question is, however, how this unity is defined. The historians who see the European past mainly in terms of a pre-history or pre-formation of American fulfilments tend to stress the unity of cultural heritage. Those who see European history as a part of an Atlantic context are more inclined to define it as a unity of fate.

Down to the end of the nineteenth century, American scholars of European history were mainly interested in the unity of heritage. It is only natural that the idea of an historical unity of fate should have impressed them more and more at the time when the United States attained the stature of a world power and became involved in the global conflicts and problems which characterize the twentieth century. This apparent shift of emphasis in the American outlook on the European past is a phenomenon of crucial importance. In dealing with it here, we have to discuss two specific problems: its origins and its historiographical consequences.

It is generally agreed that the great turning point in the development of historical writing in America falls into the last quarter of the nineteenth century. Prior to this period, American historiography was-in Leonard Krieger's words-'amateur in authorship, romantic in tone, literary in style, nationalist in mission, and multivolumed in scope'. During the I87os and 1880 os it became increasingly professional, scientific (as the phrase was), expository, and 'if not exclusively monographic at least limited in its canvas'. ${ }^{1}$ In a general survey one may thus speak of an 'amateur' and a 'professional' era, if one keeps in mind that the amateur contribution did not suddenly disappear after about 1880 . If we examine

1 Ibid. p. 238. 
the 'amateur' era of American historiography for its interest in European history, we find ourselves confronted with a striking, almost paradoxical situation. In the seventeenth and eighteenth centuries when North America was still tied to Europe politically, Americans wrote practically no European history. In the first three quarters of the nineteenth century, when the American republic consolidated its political and national identity, American men of letters wrote a number of very important works on the history of the Old World. It is, of course, true that in the Colonial period many educated Americans were aware of the European context of the American experience. Puritan historians wrote Providential history that included the traditional Christian concept of the Four Empires, the conflict of God and Satan for the souls of Christians, and the dramatic story of the Reformation and religious persecution as background for the narrative of New England. ${ }^{1}$ The historians of the Revolutionary generation had a more secular point of view, but many of them were convinced that the American Revolution was part of the history of mankind and had to be written as such. How well the leading men of this period were acquainted with the then available literature on British history has been shown in an informative study by $\mathrm{H}$. Trevor Colbourn. ${ }^{2}$ But the fact remains that in the whole Colonial and Revolutionary periods no historical work on a European subject was written in America. ${ }^{3}$

\section{II}

Not the Colonial but what is usually called the 'National' period of American historiography saw the beginning of serious and comprehensive study also in the European field. Famous names come to one's mind at once: Washington Irving, William Hickling Prescott, John Lothrop Motley. All of them wrote multivolume works and won immediate recognition as historians both in America and in Europe. Their aims were literary. They produced romantic works of art, full of pageantry and local colour. They

1 Ibid. p. 239.

2 H. Trevor Colbourn, The Lamp of Experience: Whig History and the Intellectual Origins of the American Revolution (Chapel Hill: University of North Carolina Press, I965), p. 2 I ff.

3 If we peruse the leading histories of the Colonial past and of the Revolution, we can see that the reference to the European background is in most cases very scant. It is noteworthy only in Cotton Mather's Magnalia Christi Americana ( 1702 ) and in Thomas Prince's Chronological History of New England ( 1736 ). But even here we do not perceive more than a fragmentary image of the Old World. Mather points to Europe as the site of the incomplete Reformation which was to be gloriously perfected in America. Prince presents the reader with a summary of the history of mankind as an introduction to the history of New England because he wants to show "the age of the world when this part came to be known to the other'. Krieger, loc. cit. p. 240. 
loved the great scenes, the heroic 'tableaux' of famous events and episodes. They wrote for a general public of educated readers whom they wanted to teach moral lessons and to edify. Formal composition and effect were almost as important to them as contents and documentation. ${ }^{1}$ Yet the choice of their subjects was not based upon historical picturesqueness alone. In most of their works they treated problems of European history which could either be seen as background to the early history of the American nation or be compared with certain phases of its early development. Thus Irving wrote his Columbus (1828), Prescott rose to fame with his History of the Reign of Ferdinand and Isabella, the Catholic ( $18{ }_{3} 8$ ) and Motley produced his six volumes on the Netherlands' struggle for freedom and national independence ( $1856 \mathrm{ff}$ ). All these subjects were apt to fascinate the contemporary American reader and indirectly to confirm his conviction of the distinctiveness and uniqueness of the American experience. In one form or another all these works dealt with the evolution of political, religious and individual freedom out of political and religious tyranny. Seen from this angle, Irving, Prescott and Motley fulfilled a cultural function very similar to that of Bancroft, Palfrey and their successors who treated the national theme. Irving and Prescott started out from the same point of juncture between European and American history. But the Boston gentleman of letters went much further than the enthusiastic amateur from New York whose real interests and abilities lay outside the field of disciplined historical research. In long years of labour and constant struggle to overcome his physical handicaps, Prescott built up a monumental survey of Spanish history which led from the unification of the Iberian kingdom in the fifteenth century to the height of colonial expansion and European preponderance under Philip II. The connexion of this great theme with the early history of America was not Prescott's only motive, however. There were other impulses, perhaps more objective ones: the general interest in Spanish history and culture which prevailed in the United States in the first half of the nineteenth century, the personal influence of George Ticknor, the attractiveness of an exciting subject that had not been treated before and the awareness of newly accessible sources which could be brought to the reader's attention. But that was not all. There was still another aspect which, in Prescott's view, placed the history of the Spanish nation into the general context of the course of Western civilization: the development of liberal Teutonic traditions and institutions into fruitful national vitality. The promotion of this development was, to the American historian, the great achievement of Ferdinand and Isabella.

1 David Levin, History as Romantic Art: Bancroft, Prescott, Motley, and Parkman (Stanford, California: Stanford University Press, I959), pp. 3-23. 
They had unleashed the forces of cultural energy that founded the New World, but at the same time they had created the pattern of authoritarianism which ultimately led to the extinction of individual liberties and to the decline of the Spanish empire. This tragedy was not brought about by the absolutist principle of royal power alone. Even more important was the fact that the Spanish monarchy submitted itself to the religious bigotry of the Church. Here we have the theme of Prescott's last work, the unfinished History of the Reign of Philip the Second (1 855 ff.). ${ }^{1}$

It cannot be doubted that Motley was a much less able historian than Prescott. His interests were simpler, his ideas about the historian's task more naive. Yet an obvious similarity of the historiographical aims places him close to his older New England colleague. In his representation of the contemporary American motives in writing European history Motley is much more transparent. The great theme which he discussed in his weighty volumes was 'the dangers which come from superstition and despotism and the blessings which flow from the maintenance of religious and political freedom'.2 This theme was, to him, the expression of a universal law which governs 'all bodies political as inexorably as Kepler's law controls the motion of planets. The law is Progress; the result Democracy' $^{3}$ If Prescott had written the history of Spain to show his American readers the example of a national development contrary to that of their own country, Motley described a parallel case, and he did not hesitate to point out the parallelism whenever possible. In the introduction to the first volume of The Rise of the Dutch Republic we find the following characteristic sentence: 'The maintenance of the right of the little provinces of Holland and Zeeland in the sixteenth, by Holland and England united in the seventeenth, and by the United States of America in the eighteenth centuries, forms but a single chapter in the great volume of human fate; for the so-called revolutions of Holland, England, and America, are all links of one chain.' 4 Much more than Prescott, Motley pressed the thesis of the Teutonic origins of Democratic institutions. This brought him close to Bancroft, who also saw the early history of the United States mainly in terms of a renaissance of Teutonic, i.e. AngloSaxon, traditions of freedom-traditions which had for centuries been

${ }^{1}$ Hans R. Guggisberg, 'William Hickling Prescott und das Geschichtsbewusstsein der amerikanischen Romantik', fahrbuch für Amerikastudien II (1966), I76-93; Krieger, loc. cit. p. $24 \mathrm{I}$ f.

2 John L. Motley, History of the United Netherlands from the Death of William the Silent to the Twelve Years' Truce, vol. I (London, I901), p. iv.

3 John L. Motley, Democracy, the Climax of Political Progress and the Destiny of Advanced Races: An Historical Essay (London, I 869), p. 6.

4 John L. Motley, The Rise of the Dutch Republic, vol. I (London, I896), pp. liii-lv. Cf. Krieger, loc. cit. p. 243 . 
buried under the weight of European feudalism. Motley went further than that. His admiration for the continuity of Germanic traditions both in the Old and in the New World made him overlook all the contemporary differences between German and Anglo-American culture, so that he could exclaim: 'Ever since the great rising for freedom against the Roman empire, down to this hour, Germany has been the main source of European and American culture. The common mother of nations and empires-alma mater felix prole-she still rules the thought of her vast brood of children; Franks, Goths, Saxons, Lombards, Normans, Netherlanders, AmericansGermans all.'1 With his teutonism Motley obviously stands in a historiographical tradition that can be traced back to eighteenth century England and to Montesquieu. ${ }^{2}$ As an American historian of the romantic generation he seems to anticipate some of the ideas of the later 'scientific school' and of such national historians as John Fiske, James Kendall Hosmer, and John William Burgess. ${ }^{3}$

For the romantic historians of America the study of European history had two main functions. Primarily, European history was 'prenatal' American history in the period when the destinies of the two continents were still tied to each other, or in the earlier period when American history in the proper sense had not yet begun. The secondary function was the indication of continuing political and religious conflict in the Old World at a time when these problems came to be solved in the New. The emphasis throughout lay on the common heritage of ideas. By illustrating the fruition or stagnation of these ideas in various European countries, the American historians were able indirectly to demonstrate to their readers the difference as well as the uniqueness of the American development toward democracy.

\section{III}

In the second half of the nineteenth century, and particularly after the close of the Civil War, a number of new tendencies started to dominate the general development of historical study in the United States. Together with an increasingly critical attitude toward the sources went a general acceptance of evolutionary thought. Behind this stood the influence of the German historical school on the one hand and that of Darwinism on the other. One of the most important results of the new movement was the

1 John L. Motley, 'Historic Progress and American Democracy', in Representative Selections, with Introduction, Bibliography, and Notes, ed. by Chester P. Higby and B. T. Schantz (New York, 1939), p. I05 f.; Levin, History as Romantic Art, p. 86 ff.; Hans R. Guggisberg, Das europäische Mittelalter im amerikanischen Geschichtsdenken des 19. und des frühen 20. Jahrhunderts (Basel \& Stuttgart: Helbing \& Lichtenhahn, 1964), p. 33 .

${ }^{2}$ Colbourn, The Lamp of Experience, p. 25 ff.; Guggisberg, Das europäische Mittelalter,
p. 3 I.
3 Guggisberg, op. cit. pp. 6I-5. 
reform of the teaching of history in American universities, the adoption of the seminar method and the establishment of what was called 'the school of scientific history'. The influence of the German historical school was mainly an influence on methodology. German historicism was never really integrated into American historical thought. It was only in the present century that the philosophical framework of nineteenth century German historiography began to be studied and appreciated in the United States. Again, this happened under a foreign influence, namely under that of the German refugee historians, many of whom had come from the school of Friedrich Meinecke. By the disciples of the American 'scientific school' of the late nineteenth century Ranke was very highly praised, but his works were not widely read. ${ }^{1}$

To the study of European history in America, the rise of the 'scientific school' did not bring immediate changes in outlook. The emphasis on the continuity of cultural heritage persisted, and the approach remained mainly chronological. To most students of the famous seminar at Johns Hopkins which, under the leadership of Herbert Baxter Adams, became the most important centre of the 'scientific school', European history was of real interest only as long as it could be seen as a development preceding the Colonial period of North America. The interest of the 'scientific historians' was thus limited to the field of medieval institutions, mainly of Anglo-Saxon England. Teutonism, now as a 'scientific' thesis of historical continuity, was in full bloom. It flourished not only at Johns Hopkins, but also at Harvard, where the somewhat more critical Henry Adams had introduced the new methods of teaching and research, and at Columbia, where John William Burgess became one of its most outspoken advocates. ${ }^{2}$ It cannot be overlooked that the 'scientific school' also produced a number of historians who, in their later lives, became specialists in European history. We shall see, however, that the development of their European interests was mostly due to other and stronger influences than those they had met in their graduate school days.

Outside the history seminars, European history continued to be written in the traditional fashion. Large works on great themes were produced, some of which have kept their scholarly validity for a long time. The emphasis on European-American continuity was still in many cases based on the religious motif. But no more than in the earlier period can this continuing focus upon religion be explained as a pure and general concern

1 Jurgen Herbst, The German Historical School in American Scholarship (Ithaca, New York: Cornell University Press, r 965), pp. 99-I 28. Cf. George G. Iggers, 'The Image of Ranke in American and German Historical Thought', History and Theory 2 (1962), 17-40.

2 Ibid. p. I I 2 ff.; Herbst, op. cit. p. I I 2 ff.; Guggisberg, op. cit. p. 63. 
for religious history as such. Religion functioned-if we may quote Leonard Krieger once more-'... as a constant principle of identity in terms of which the changing modes of Western culture acquired meaning and coherence for Americans. In a century of political isolation the traditional religious motif remained the main substantive theme locating America in world history'. ${ }^{1}$ A general tendency toward specialization can be observed in these new works. In some of them the scientific concepts of the time are clearly discernible as the starting points from which the investigation of the past was undertaken. Both John William Draper and Andrew Dickson White projected an intellectual conflict of their own time into the Ancient and Medieval past of the Old World: the struggle between science and religion. Draper was a trained physiologist who became an amateur historian because he believed in the possibility of investigating the past of mankind with the methods and tools of science. He was an evolutionist and a firm adherent of Comtean positivism. As the author of a History of the Intellectual Development of Europe (1863) and a concise History of the Conflict between Religion and Science (1874) he appears to the modern reader in the somewhat anachronistic role of a belated eighteenth century encyclopedist. His aim was to show the contrast between the dark 'age of faith', which lasted to the end of the fifteenth century, and the enlightened 'age of reason' which began with the Renaissance and found its fulfilment in modern America. White was less onesided in his historical views, but their general pattern was the same. This becomes obvious already in the title of his most significant historiographical achievement, the History of the Warfare of Science with Theology in Christendom (1896). White was a professional historian who later became a leading university reformer and eventually a diplomat. He wrote on European history out of his sense of what was needed in America. As he says in his Autobiography (1905), he desired to confront his readers with the European past to help them 'understand our own time and its problems in the light of history'.2 In his treatment of the sources he was more critical than Draper, but like his older contemporary he sought to demonstrate the fundamental necessity of a liberal attitude in religious matters in order to secure cultural progress. Behind this pragmatic aspiration stood the conflicts which accompanied the foundation of Cornell University as a non-sectarian institution. Here, White was directly involved: he was the first president of this new American university.

The conjunction of growing historical criticism with the preservation of the thematic tradition found its most impressive demonstration in the

1 Kricger, loc. cit. p. 245.

2 Autobiography of Andrew Dickson White (New York, 1905), vol. 1, p. 83. 
works of Henry Charles Lea. This wealthy Philadelphia publisher again wrote as an amateur, but he turned out to be a more significant historian than many of his professional contemporaries. His contribution was twofold: like his 'scientific' colleagues he developed institutional history as the most reliable basis for the study of any period. In addition to this he refrained from making particular moral judgements, because he believed that the historian should insist on the priority of the facts and let the facts alone 'teach their appropriate lesson'. Yet he remained within the historiographical tradition of his century. As a historian of institutions and more particularly of legal institutions he became a specialist on the history of ecclesiastical law. His greatest works were the History of the Inquisition in the Middle Ages (1888) and the History of the Inquisition in Spain (1906-7). In a number of auxiliary studies which appeared before, between, or after the two magna opera, Lea investigated such themes of ecclestiastical law as auricular confession, indulgences, sacerdotal celibacy, and the persecution of witchcraft. Unlike most of his professional contemporaries of the 'scientific school', Lea had never studied in Germany nor been a member of one of the new history seminars in the United States. Nevertheless, he became one of the great masters of historical criticism and rose to international renown as well as to the presidency of the American Historical Association (1903). Together with Prescott he may be counted among the greatest American pioneers in establishing the European background of American history. Still, his image of the European past, and particularly of the Middle Ages, remained onesided and pragmatic. It was dominated by dark colours. It cannot be said that Lea did not see the bright ones, but he was obviously not interested in reproducing them. Basically, Lea was not concerned with the cultural unity and uniqueness of the Middle Ages but with the spirit that stood behind the institutions of the Church and caused these institutions to become obstacles to the development of 'human progress'. 'Human progress', to him, was liberty of conscience, tolerance and democracy. Like most of his educated fellowAmericans, Lea believed that the preservation of these ideals was the sacred task of his nation. To the historically minded readers of this nation he demonstrated a great example of what had happened in the (preAmerican) European past when men had not yet realized how important it was to preserve these ideals. Although he was technically far more advanced, Lea's historiographical achievement, when viewed from this angle, may certainly be compared to that of Prescott. ${ }^{1}$

Among Lea's contemporaries there were several historians who also addressed themselves to the study of European Church History. Most of

${ }^{1}$ Guggisberg, op. cit. p. 85 ff. Cf. Krieger, loc. cit. p. 248 ff. 
them wrote on the Reformation and on the history of particular Protestant movements. Although their writings were generally less comprehensive in scope and more specialized in the treatment of their subjects, they too emphasized the chronological connexion between the European and the American past. The conception of the unity of heritage was easier to defend in such books than it had been for Lea in his histories of the Inquisition. Moreover, a new motive of historiographical endeavour became visible: the author's self-identification with a specific denominational tradition that had started in the European Reformation and then taken roots also in the New World. This self-identification could, of course, engender a kind of popular literature without any historiographical value. But it could also lead to the production of informative works of high scholarly quality. That this happened is convincingly shown in Henry Baird's volumes on the history of French Protestantism, in Samuel Macauley Jackson's biography of $Z$ wingli and in Williston Walker's book on Calvin. ${ }^{1}$ Denominational identification has furthered American investigations of European Church History down to our day. It must be recognized as one of the reasons why relatively many American scholars have become leading authorities particularly in the fields of Anabaptism and evangelical radicalism, i.e. in fields which have for a long time been left unploughed by European scholars. ${ }^{2}$

\section{IV}

The nineteenth century American perspective on European history was not, as we have seen, fundamentally changed by the ideas and methods of the 'scientific school'. The thematic tradition and the preponderance of the ideas of continuity and unity of the cultural heritage persisted for an amazingly long time. It was only in the last decade of the century that the first intimation of a fundamental re-orientation came into the light. Here again, our attention is drawn toward the work of an outsider. In several respects, Alfred 'T. Mahan's famous trilogy on the influence of sea power upon history appears to the modern reader as a traditional nineteenth century product. ${ }^{3}$ It covers a general theme in great detail; its emphasis is

${ }^{1}$ Henry M. Baird, History of the Rise of the Huguenots of France (1879), Huguenots and Henry of Navarre (1886), Huguenots and the Revocation of the Edict of Nantes (1895); Samuel M. Jackson, Huldreich Zwingli (1900); Williston Walker, fohn Calvin, The Organizer of Reformed Protestantism, $1509-1564$ (1906).

2 Cf. the works of Roland H. Bainton, Earl Morse Wilbur, Harold Bender, George $\mathrm{H}$. Williams and many others. The significance of the present American contribution to Reformation research is easily recognized in such periodicals as Church History, The Mennonite Quarterly Review, and the German-Anerican Archiv für Reformationsgeschichte.

3 The Influence of Sea Power upon History, $1660-1783$ (1890); The Influence of Sea Power upon the French Revolution and Empire, I793-1812 (1893); Sea Power in Its Relation to the War of 1812 (1905). 
upon narrative synthesis and upon the reinterpretation of published materials; its style is formal and ponderous at times. The purpose of the work is pragmatic; the author admits that 'the practical object... is to draw from the lessons of history inferences applicable to one's own country and service'. ${ }^{1}$

The new element was first of all the subject. For the first time in the nineteenth century, an American author dealt with the European past outside the traditional fields of legal, institutional, moral or ecclesiastical history. And he even went as far as to devaluate these preoccupations of his predecessors in favour of secular interests and power as the prime moving forces of history. Although this position had long before become a familiar one in domestic history, it was new in the American perspective on Europe. Like the earlier authors, Mahan was concerned with the connexions between European and American history; this is obvious already in the first two volumes and particularly in the third, which deals with the War of 1812 . But behind his narrative lay an expanded concept of the AmericanEuropean community. It was no longer only a community of continuing traditions but a community of simultaneous destinies on both sides of the Atlantic Ocean. Mahan was the first American scholar of European history who saw the Old World and his own nation as equal partners in a specific development of political involvement. With this he became the harbinger of a new American outlook on the European past-of an outlook which was eventually to be dominated by the idea of the unity of fate. This re-orientation produced general results only after the turn of the century when political events were making the rapprochement of the American and European orbits more explicit.

Although the 'scientific school' had not directly furthered the study of European history, it had drawn the attention of many American scholars toward the European background of their own national history. In spite of the fact that many former pupils of the founders of the 'scientific school' eventually became severe critics of their teachers' ideas, a number of important general impulses had come out of the seminars of Herbert B. Adams and his contemporaries. The monograph, the doctoral dissertation and the textbook became the typical means of scholarly communication and increasingly superseded the multivolume treatments of general themes. This did not apply only to domestic history, but in the course of time it also changed the external appearance of the study of the European past. Some 'scientific historians', while specializing in the American Colonial period, became increasingly interested in the immediate background of British history and established the so-called 'imperial tradition'.

1 The Influence of Sea Power upon History, ${ }_{1660-1783}$ (London: 1965, repr.), p. 83. 
We think of Charles M. Andrews and Herbert Levi Osgood, but quite particularly of George Louis Beer, who became the greatest American authority on the British Colonial System (1908-12).

More influential than the impulses of the 'scientific school', however, were those of the group of younger scholars who gathered around James Harvey Robinson at Columbia and adhered to the ideas he had laid down in his book on The New History (1912). These ideas do not require detailed enumeration here. What we must not overlook, however, is the fact that in the minds of Robinson and his followers the European dimension had always been prominent. Among these scholars there were several experts in European history. Robinson himself was one. During the formative phase of the movement before World War I Charles A. Beard not only collaborated on several textbooks on European history but also produced a monograph on The Office of the Fustice of the Peace in England (1904). Carl Becker had not yet published the works that were to make him well known as an authority on American as well as on European history, but his dual interests reflected themselves already in his early teaching career. Among Robinson's first disciples, James T. Shotwell, Carlton Hayes and Lynn Thorndike were to become prominent in different areas of European history. ${ }^{1}$ When looking upon the Old World, the New Historians emphasized the following principles with particular insistence: history is a continuous process; its chief goal is to learn from the past in order to contribute not only to the understanding but to the improvement of the present. The historian must encompass all the varied interests and activities of man; he must try to understand conditions and institutions and not simply reproduce the facts. He must take into account the insights gained by the social sciences. Many of these ideas were rather a modernization of than an antithesis to the established tradition. But as far as European history was concerned, the impulses of the New History undoubtedly caused a general intensification of interest. This interest was firmly based on the consciousness of common contemporary connexions and common destinies. It was therefore only natural that the New Historians desired to expand the thematic horizon: they called for more intensive study also of modern European history.

The experience of World War I did much to fulfil this wish. It exhibited the community of American and European political interests and the unity of fate within Western Civilization in so fundamental a way as to make it predominant in the approach to European history for more than one generation of historians. From 1917 to the crisis of the 1930 os the emphasis was primarily on the history of external relations. Thereafter 1 Krieger, loc. cit. p. $260 \mathrm{f}$. 
one can observe a growing interest also in domestic problems of European countries. During the war, many leading historians had become acquainted with the complexity of diplomatic relations and foreign policy through their collaboration in organizations such as the Board for Historical Service. Prominent specialists of European history were called to serve as experts in the American delegation at the Paris Peace Conference. To them and to their later colleagues the war evinced the political community between America and Europe. It confirmed their conviction that the study of diplomatic history was of particular importance also for the determination of America's role in the history of the world. ${ }^{1}$

During the period of isolationism the American interest in modern European history did not abate but kept on growing persistently. This fact can certainly be understood as an expression of the 'antithetical magnetism' of Europe for American intellectuals which Daniel Boorstin has pointed out as a general characteristic of the $1920 .^{2}$ Diplomatic history was indeed the field in which a great number of outstanding works were produced. Most of them dealt with the events that had led to the joint Allied war- and peace-making enterprises, while some reached further back into the international developments of the last three decades of the nineteenth century. It was in this field also that a great national controversy erupted: the conflict between the revisionist and anti-revisionist interpretations of the origins of the war and of American intervention. This conflict was observed with particular interest in Germany, and the most prominent exponent of revisionism, Harry Elmer Barnes, could for a time enjoy the admiring appreciation of a considerable German audience. Barnes was to take part again in the controversy about Franklin Roosevelt's foreign policy which was fought out among American historians after $1945 .^{3}$

Diplomatic history was the most prominent but not the only field of modern European history to which American historians addressed themselves between the two world wars. Many turned to economic and social history or to the theme of nationalism and imperialism. These subjects were studied particularly at Columbia, where Shotwell and Hayes continued to represent the traditions of the New History.

Besides this great expansion of American interest in modern European history, the study of the Middle Ages and of the early modern period had

1 Ibid. pp. 263, $269 \mathrm{ff}$.

2 Daniel Boorstin, America and the Image of Europe (New York, I960), p. $23 \mathrm{ff}$.

3 Warren I. Cohen, The American Revisionists: The Lessons of Intervention in World War I (Chicago, 1967). Günter Moltmann, 'Revisionist Historiography in the United States and its Importance for German-American Relations in the Weimar Period', Deutschland und die USA 1918-1933 (Schriftenreihe des internationalen Schulbuchinstituts, Bd. I3, Braunschweig, 1968). 
by no means died out. On the contrary: American medievalism reached the high level of its quality which has remained traditional down to our day, in the same 1920 shen the intensification of interest in modern Europe took place. ${ }^{1}$ Many of the leading scholars had received their training in the seminars of the 'scientific school' and had consequently started out on their professional career as specialists of institutional history. Like their colleagues in the modern field, they also began to expand the range of their interests under the influence of the New History. After World War I they came to the European archives in increasing numbers, started to explore them systematically, and soon they felt fully capable of competing with their European fellow-medievalists on an equal level of scholarship. By I930 several successful attempts had already been undertaken to present the history of medieval culture as a whole or in some of its most important aspects. A number of these works have become classics in their field on both sides of the Atlantic Ocean, e.g. Henry Osborn Taylor's Medieval Mind (I9II) or Charles Homer Haskins's Renaissance of the Trelfth Century (1927), not to speak of that unique and truly 'unclassifiable' masterpiece of the old Henry Adams, Mont-Saint-Michel and Chartres (1913). Alongside these extraordinary achievements went many reliable textbooks and source-collections for the benefit of students and a great number of monographs or extensive works on special topics. Of particular importance was the American contribution to the history of medieval science, notably in the weighty volumes of George Sarton and Lynn Thorndike. Out of these works came a remarkably severe attack upon the Burckhardtian concept of the Renaissance. In their emphasis on the continuous and unbroken expansion of man's knowledge of nature, these American historians saw the Renaissance not as a new revival of intellectual forces but rather as a period of rest between the Middle Ages and the Enlightenment, or even as a period of regression." This 'revolt of the medievalists' against the established pattern of historical periodization was parallelled by similar attempts at re-orientation in Europe, but nowhere

1 The visible symbol of this impressive development was the foundation, in 1925 , of the 'Mediaeval Academy of America'. Since 1926 this organization of scholars published the journal Speculum. It was to be the counterpart of the Gournal of Modern History which was founded three years later as the professional periodical for European history since the Middle Ages. Although the number of trained medievalists was still comparatively small in the I920s and I930s, their interests covered a wide horizon. Cf. Guggisberg, op. cit. p. $173 \mathrm{f}$.

2 George Sarton, Introduction to the History of Science, 3 vols. in 5 parts (Baltimore, 1927-1948); Lynn Thorndike, $A$ History of Magic and Experimental Science, 8 vols. (New York, 1923-1958). See especially Sarton's essay on 'Science in the Renaissance', in J. W. Thompson, G. Rowley, F. Schevill, G. Sarton, The Civilization of the Renaissance (Chicago, 1929), p. 79. Hans R. Guggisberg, 'Jacob Burckhardt und Amerika', Fahrbuch für Amerikastudien $\mathrm{x}_{3}$ (1968), 53-68. 
was it so exclusively based upon the idea of the continuity of scientific progress as in the United States. ${ }^{1}$ American medievalists of the 1920 s and early 1930 s excelled in other fields, too, notably in economic history, paleography and in history of art, but here their interpretive achievements were, on the whole, less original. ${ }^{2}$

In general, the American scholar's outlook on the Middle Ages was naturally free from national prejudice. This was, as Haskins himself pointed out, his great advantage, because it enabled him to see common elements of medieval civilization more clearly than his European confrère. ${ }^{3}$ Indeed, we observe American medievalists again and again emphasizing the cultural unity of the Middle Ages in contrast to the diversity of the modern world. And in addition to this we find that the American medievalists of the I920s and early I930s were proudly conscious of the fact that the intellectual heritage of the Middle Ages belonged to them just as much as it belonged to the Europeans who seemed culturally closer to it.

If the American historian who, in the years between the two world wars, devoted himself to the study of modern Europe, emphasized the AmericanEuropean unity of fate, his colleague in the medieval field quite naturally tended to stress the conception of the unity of heritage. This has not changed to the present day. The American contribution to European history has continued to receive fruitful impulses, first of all from the refugee scholars who came to the United States as victims of National Socialist persecution, and then again from the experience of the Second World War. As a consequence of all this, the American awareness of the community of destinies within the Western or Atlantic world has become more and more distinct. ${ }^{4}$ It stands behind the works of such scholars of 'Atlantic history', as Preserved Smith, Carl Becker, Louis Gottschalk and Crane Brinton. It provided the intellectual basis on which the Fournal of the History of Ideas was founded in 1940 . In more recent years it has again become evident in Robert R. Palmer's panoramic study on The Age of the Democratic Revolution (1959-64).

The extent of the refugee scholars' influence upon the development of the study of European history in the United States is still very difficult to characterize and to evaluate. We cannot and shall not venture to do it here. In order to attain a reasonably reliable basis for a general judgment we would have to consider not only the works of the refugee scholars themselves

1 Wallace K. Ferguson, The Renaissance in Historical Thought: Five Centuries of Interpretation (Boston \& New York, I948), p. $329 \mathrm{ff}$.

2 Guggisberg, Das Mittelalter, pp. 137-50.

3 Charles Homer Haskins, 'European History and American Scholarship', American Historical Review 28 (January 1923), 226.

4 Krieger, loc. cit. p. $288 \mathrm{ff}$. 
but also those of their many pupils. It cannot be doubted that through their writing and teaching the European emigrants have greatly intensified and deepened the American understanding of the European past in a great number of more or less specialized fields. In some of them, e.g. in medieval studies or in contemporary history, the definition of a specifically American outlook must henceforth be undertaken with very careful differentiation. One can also observe that the guild of American historians, pupils as well as colleagues, has not failed to recognize the merits of the refugee scholars. This becomes evident in innumerable prefaces of books, in many memorial articles and also in some 'Festschriften'. It became impressively manifest when, in December I966, Hajo Holborn, the great German-born teacher of the history of Germany at Yale, was elected president of the American Historical Association. ${ }^{1}$

World War II expanded the horizon of American historians also beyond the geographical border lines of Europe. It has opened to them new vistas in the Asian and African world. As for Europe, the interest is certainly not diminishing. The production of learned books has become so vast, that the European observer can do no more than try to keep track of what happens in the field of his own specialization. ${ }^{2}$

It seems that in spite of this enormous expansion of scholarly interest and activity in European history, the general American perspectives upon the Old World's past have not undergone any fundamental changes since the time after World War I. We may safely assume that the great majority of American scholars in the field of European history could still agree with

${ }^{1}$ On the influence exerted by refugee scholars, notably from Germany and Austria cf. Gerald Stourzh, 'Die deutschsprachige Emigration in den Vereinigten Staaten: Geschichtswissenschaft und politische Wissenschaft', Jahrbuch für Amerikastudien ro (1965), pp. 59-77, 232-66; rr (1966), pp. 260-317. Cf. also Leonard Krieger and Fritz Stern, 'Editors' Introduction', The Responsibility of Power, Historical Essays in Honor of Hajo Holborn (Garden City, N. Y., 1967); Franz L. Neumann, 'The Social Sciences', in Neumann et al., The Cultural Migration: The European Scholar in America (Philadelphia, 1953), pp. 4-26; Donald Fleming \& Bernard Baylin (eds.), The Intellectual Migration, Europe and America, 1930-1960 (Cambridge, Mass., 1969). This volume, interesting and many-sided as it is, contains surprisingly scant information on refugee historians.

2 Another problem, which we cannot discuss here, is the question as to the reception and influence of the theories and methods of the 'Ecole des Annales' upon contemporary American historiography. That there is such an influence cannot be doubted, but it would not be an easy one to describe. It is astonishing to note how long it took for the works of Mare Bloch to be translated and published in the U.S.A. The writings of Lucien Febvre do not seem to have aroused much general interest among American historians. F. Braudel's La méditerranée et le monde méditerranéen à l'époque de Philippe II (1949, I 966) has been very severely criticized by Bernard Baylin, Journal of Economic History II (195I), pp. 277-82. One can perhaps say that the 'Ecole' is not very influential as a block but some of its works, ideas and methods have been taken up with sympathy and interest. Cf. Joseph R. Strayer's 'Introduction' to Bloch's The Historian's Craft (Manchester and New York, 1954). For information on this point I am indebted to Professor R. S. Lopez of Yale University. 


\section{I8 Hans R. Guggisberg}

what Charles H. Haskins has already said in 1923: 'Whether we look at Europe genetically as the source of our civilization, or pragmatically as a large part of the world in which we live, we cannot ignore the vital connections between Europe and America, their histories ultimately but one.'1

1 Charles Homer Haskins, 'European History and American Scholarship', p. 215. Cf. Chester P. Higby, 'The Present Status of Modern European History in the United States', Fournal of Modern History I (March 1929), 3-8.

This essay is a revision of a lecture given at the E.A.A.S. conference in Rome in the fall of 1967. 